\title{
THE PRESENCE OF TWO PERMEABILITY GLOBULINS IN HUMAN SERUM *
}

\author{
By LAWRENCE J. KAGEN, JOHN P. LEDDY, AND ELMER L. BECKER \\ (From the Department of Immunochemistry, Division of Communicable Disease and \\ Immunology, Walter Reed Army Institute of Research, Walter Reed Army \\ Medical Center, Washington, D. C. )
}

(Submitted for publication January 24, 1963; accepted May 2, 1963)

Among the substances in mammalian sera that increase vascular permeability under experimental conditions are two globulins, the permeability globulins. The first, kallikrein, was originally described by Frey (2); the second, PF/dil, was first described by Mackay, Miles, Shachter, and Wilhelm (3). The permeability-increasing activity of kallikrein appears to be mediated through the enzymatic generation of the polypeptide bradykinin (4), whereas the mechanism of PF/dil's action is still uncertain. The role of the permeability globulins in the biology of living organisms is not entirely known. Bradykinin is one of the most potent vasodilator substances known (5). It not only causes vasodilation and increased vascular permeability, but produces pain and the local accumulation of leukocytes (6), and therefore has been suggested as a mediator of the inflammatory response. The permeability globulins have not as yet been implicated directly in the pathogenesis of a known human disease; however, there is evidence to indicate that a basic defect in the genetically determined disease hereditary angioneurotic edema is the lack of a permeability globulin inhibitor (7). Kallikrein may, in addition, have a hormonal role in bringing about the functional vasodilatation of actively secreting salivary glands and the heat vasodilatation of skin (8). Further, hypotensive vasodilator substances similar to bradykinin have been evoked in tissues by axon reflex (9). It has been suggested that activation of permeability and hypotensive factors of this sort may be operative in states of shock.

Both kallikrein and PF/dil can be obtained from serum after proper activation, and both cause hypotensive responses in addition to increasing vascular permeability in test animals. Both have associated esterase activity, and are inhibited by diisopropyl phosphofluoridate (DFP) and soy-

* A preliminary report of this work has appeared (1). bean trypsin inhibitor (10-12). Because of these similarities, it has been suggested that $\mathrm{PF} / \mathrm{dil}$ and kallikrein are the same (13). PF/dil, however, is in some instances not a kininogenase (14). Moreover, Miles has reported PF/dil to be an $\alpha_{2}$-globulin in the guinea pig, whereas Davies and Lowe (15) have shown DFP-inhibitable permeability activity in the $\gamma$-globulin portion of activated guinea-pig serum. Whether there is more than one permeability globulin in this species, or whether these differences are due to artifacts of the different preparative procedures the previous reports leave unclear. We wish to report separation of two permeability globulins from human serum by the use of starch-block electrophoresis and column chromatography.

\section{METHODS}

Blood samples were drawn under sterile conditions from normal male donors into plastic syringes or tubing and then transferred to glass centrifuge vessels, where they were kept at room temperature (about $24^{\circ} \mathrm{C}$ ) for 1 to 2 hours. Formed clots were then rimmed with sterile wooden applicator sticks and separated from serum by centrifugation at $5^{\circ} \mathrm{C}$. Samples of serum were stored frozen at $-15^{\circ} \mathrm{C}$.

Five-molar diisopropyl phosphofluoridate (DFP); 1 soybean trypsin inhibitor crystallized 5 times; ${ }^{2}$ diphenhydramine hydrochloride, ${ }^{3} 10 \mathrm{mg}$ per $\mathrm{ml}$ as an antihistaminic agent; Nair, 4 containing calcium thioglycollate, as a depilatory substance before bioassay; and 6BX Pontamine Sky Blue ${ }^{5}$ were used.

Bioassay of permeability activity was done by injecting $0.2 \mathrm{ml}$ of a given solution intradermally into white, Detrick-Hartley guinea pigs, weighing 300 to $400 \mathrm{~g}$, that had received an iv injection of $0.5 \mathrm{ml}$ of a solution of $3 \mathrm{~g}$ Pontamine Sky Blue per $100 \mathrm{ml} 15$ minutes before. The method is adapted from that of Miles and Wilhelm

1 From Dr. Bernard Jandorf, Army Chemical Center, Md.; Merck Sharp \& Dohme, Inc., Philadelphia, Pa.

${ }^{2}$ Mann Research Laboratories, Inc., New York, N. Y.

3 Benadryl, Parke, Davis \& Co., Detroit, Mich.

4 Carter Products, Inc., New York, N. Y.

${ }^{5}$ E. I. duPont de Nemours and Co., Wilmington, Del. 
(16). Activity was recorded as the average of two perpendicular diameters of the resulting blue lesions. In certain experiments, a semiquantitative scale was used by which $4+$ indicates dark blue lesions over $6 \mathrm{~mm}$ in size; $3+$, lighter lesions over $6 \mathrm{~mm} ; 2+$, blue lesions larger than control saline injections but under $6 \mathrm{~mm}$; and $1+$, lighter lesions. Duplicate injections were made in each animal in the skin of the back, which 2 to 4 hours earlier was shaved and depilated with Nair. Animals of a single sex were used in each experiment, although the sex varied in different experiments. The principles of laboratory animal care as promulgated by the National Society for Medical Research were observed.

Ion-exchange column chromatography using $0.92 \mathrm{mEq}$ DEAE cellulose per $\mathbf{g}$ as absorbent was carried out essentially as described by Sober, Gutter, Wyckoff, and Peterson (17). Starting and final buffers (except as indicated in the legend of Figure 3) were adjusted to the same $\mathrm{pH}$ as the DEAE cellulose so that protein elution was carried out at constant $\mathrm{pH}$ by means of a variable ionic gradient. The gradient was developed and applied with a Varigrad device (18). The concentration of buffers in each of the 9 Varigrad chambers is given in the figure legends as the percentage of final buffer in each chamber. Buffer ionic strength was recorded in units of electrical conductivity (mhos). Permeability activity of chromatographic fractions was assayed in 1:3 or 1:4 dilutions of $0.15 \mathrm{M}$ saline to prevent the injection of fluids of extremely high or low tonicity. After such dilution, neither the starting nor the final buffer caused increased skin bluing.

Preparative starch-block electrophoresis was carried out in the manner described by Kunkel and Slater (19). Potato starch ${ }^{7}$ washed and resuspended in electrophoresis buffer (barbital at $\mathrm{pH} 8.6, \mu$ 0.05) was the medium. The block was contained in a $31-\times 20-\times 1.5-\mathrm{cm}$ Lucite mold with three narrow channels created by the insertion of Lucite partitions, making it possible to run three samples simultaneously, under the same conditions. The samples were applied in troughs $1 \mathrm{~cm}$ wide and $1 \mathrm{~cm}$ deep; details of applied current and sample size are noted in appropriate figure legends. Plastic bags filled with crushed ice were placed over and under the block during the run to prevent internal overheating. At the end of the run, the block was cut into segments that were then mechanically stirred with equal volumes of $0.15 \mathrm{M} \mathrm{NaCl}$. The resulting supernatant fluids were assayed for protein concentration and bioactivity. Initially, dialysis to remove residual barbital buffer was performed before a test of permeability activity. There was, however, no difference in bioactivity between dialyzed and undialyzed eluates, so dialysis was not performed in later electrophoretic experiments.

Fractionation of whole serum was performed at $-5^{\circ} \mathrm{C}$ by method 10 of Cohn and associates (20). Protein concentration was determined by measurement of the optical density of solutions at $280 \mathrm{~m} \mu$ in a Beckman spectropho-

- Selectacel, Brown Company, New York, N. Y.

7 Mallinckrodt Chemical Works, St. Louis, Mo. tometer. With solutions in barbital buffer, the Lowry modification of the Folin-Ciocalteu method was used (21). All chemical and electrophoretic procedures, with the exception of the Cohn fractionation, were carried out in a cold room at 1 to $2^{\circ} \mathrm{C}$. Samples for bioassay were warmed to room temperature before use.

\section{EXPERIMENTAL PROCEDURES AND RESULTS}

Starch-block electrophoretic patterns of protein concentration and permeability activity of normal human sera. Individual samples of serum were subjected to preparative starch-block electrophoresis. Figure 1 shows the results obtained with sera of five, normal young men. The permeability

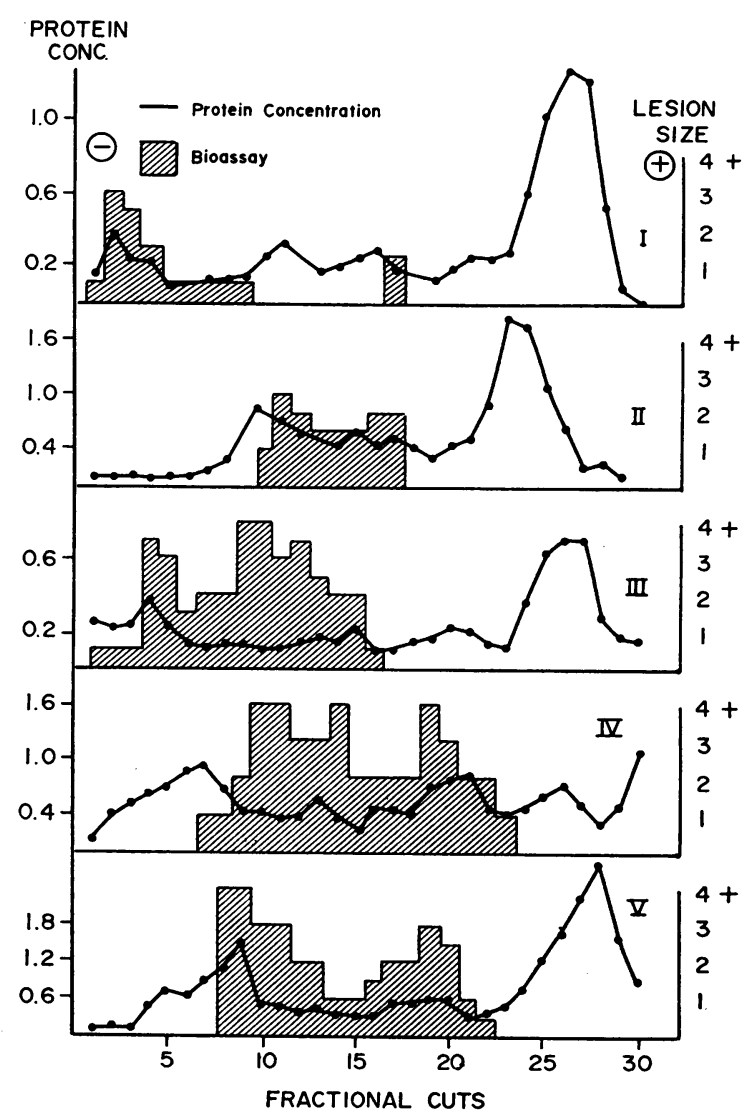

Fig. 1. Electrophoretic patterns of whole human SERUM. Protein concentration expressed as optical density at $700 \mathrm{~m} \mu$ determined by Folin phenol method. Fractional cuts are $1 \mathrm{~cm}$ wide. See Methods for scale of lesion size. Serum I: $8.5 \mathrm{ml}$, origin = segment 11 , $500 \mathrm{v}, 70 \mathrm{ma}, 15$ hours; II : $11.0 \mathrm{ml}$, origin = segment 13 , $600 \mathrm{v}, 50$ to $70 \mathrm{ma}, 14$ hours; III : $11.0 \mathrm{ml}$, origin = segment $12,600 \mathrm{v}, 100$ ma., $15 \frac{1}{2}$ hours; IV : $7.0 \mathrm{ml}$, origin $=$ segment $13,600 \mathrm{v}, 100$ to $120 \mathrm{ma}, 18$ hours; and V: $4.8 \mathrm{ml}$, origin = segment $13,600 \mathrm{v}, 100$ to $120 \mathrm{ma}, 18$ hours . 
activity of starch-block eluates can be seen in broad, merging zones extending from the $\gamma$ - to the $\beta$-globulins. A major portion or peak of activity in each of these cases has moved with the $\beta$-globulins, while another portion seems to reside principally in the "fast" $\gamma$-globulin zone. These results indicate not only the possibility of recovering permeability globulins from preparative electrophoresis, but suggest the presence of more than one globulin permeability factor.

Figure 2 depicts the pattern of activity seen in another group of men's sera. Here, although the pattern of protein distribution is similar, permeability activity occurs chiefly in the $\beta$-globulin zone. Since different sera show different proportions of $\gamma$ - and $\beta$-globulin activity, the suggestion of the presence of at least two factors is supported. To

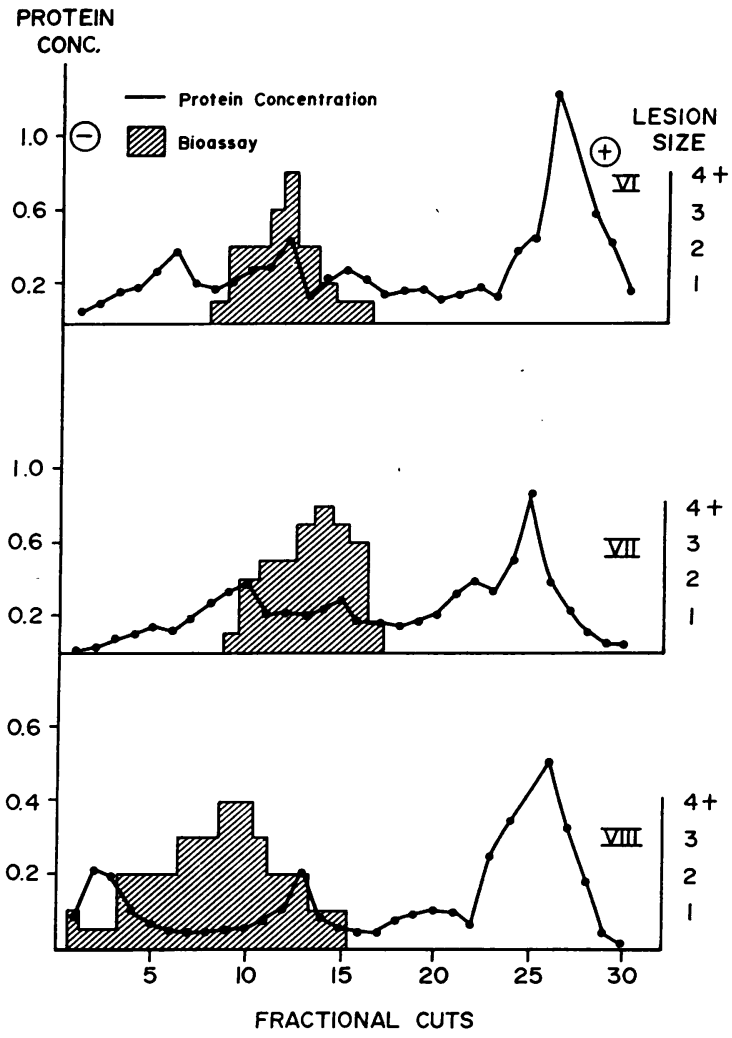

Fig. 2. Electrophoretic patterns of whole humaN SERUM. Protein concentration expressed as optical density at $700 \mathrm{~m} \mu$ determined by Folin phenol method. Fractional cuts are $1 \mathrm{~cm}$ wide. Serum VI: $8.0 \mathrm{ml}$, origin = segment $11,620 \mathrm{v}, 100$ to $120 \mathrm{ma}, 20$ hours; VII : $7.00 \mathrm{ml}$, origin $=$ segment $14,500 \mathrm{v}, 90$ to $120 \mathrm{ma}, 15 \frac{1}{2}$ hours ; and VIII : $4.2 \mathrm{ml}$, origin = segment $12,600 \mathrm{v}, 100$ to $120 \mathrm{ma}$, $15 \frac{1}{2}$ hours.

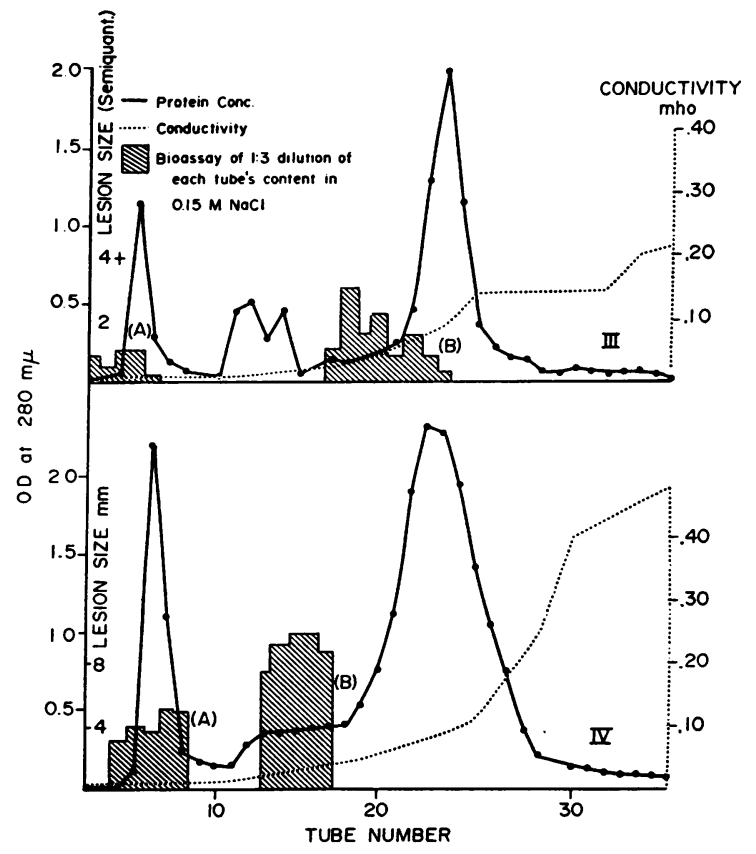

Fig. 3. DEAE-CELlulose Chromatographic PATterns of whole human Serum. Serum III $(3.8 \mathrm{ml})$ : starting buffer $0.005 \mathrm{M}$ phosphate, conductivity $0.0069 \mathrm{mhos}, \mathrm{pH}$ 8.10 , final buffer $0.0125 \mathrm{M}$ phosphate $+1 \mathrm{M} \mathrm{NaCl}$, conductivity, 0.459 mhos, $\mathrm{pH} 8.10,10 \mathrm{ml}$ collected in each tube; column $20 \times 2 \mathrm{~cm}$ packed under $6 \mathrm{lbs}$ per inch $^{2}$ pressure (about $9 \mathrm{~g}$ DEAE cellulose); concentration of final buffer in Varigrad chamber $1,0 \% ; 2,16 \% ; 3,2 \% ; 4$, $9 \% ; 5,9 \% ; 6,2 \% ; 7,20 \% ; 8,30 \%$; and $9,100 \%$. Serum IV $(1 \mathrm{ml})$ : starting buffer $0.005 \mathrm{M}$ phosphate, conductivity 0.007 mhos, $\mathrm{pH} 8.10$; final buffer $0.012 \mathrm{M}$ phosphate $+1 \mathrm{M} \mathrm{NaCl}$, conductivity 0.459 mhos, $\mathrm{pH} 5.5 ; 10 \mathrm{ml}$ collected in each tube; column $26 \times 1 \mathrm{~cm}$ packed under 8 to $10 \mathrm{lbs}$ per inch $^{2}$ pressure (about $3 \mathrm{~g} \mathrm{DEAE} \mathrm{cellu-}$ lose); concentration of final buffer in Varigrad chamber $1,0 \% ; 2,2 \% ; 3,2 \% ; 4,10 \% ; 5,10 \% ; 6,2 \% ; 7,20 \%$; $8,30 \%$; and $9,100 \%$.

explore this possibility, ion-exchange chromatography of whole serum was carried out.

$D E A E$-cellulose column chromatographic patterns of protein concentration and permeability activity of normal human sera. Figure 3 shows the results obtained by DEAE-cellulose chromatographic separation of the sera of two young men. (These are the same sera as sera III and IV, Figure 1.) The dotted line in the figures represents the rising ionic strength, plotted in units of electrical conductivity; the unbroken line is a plot of protein concentration. In both samples, an initial protein peak representing chiefly the serum $\gamma$-globulins with little binding affinity for the 
TABLE I

Permeability activity of ethanol fractions of pooled human serum

\begin{tabular}{|c|c|c|c|}
\hline Fraction* & $\begin{array}{l}\text { Protein con- } \\
\text { centrationt }\end{array}$ & Major components $\ddagger$ & Bioassay \\
\hline & $m g / m l$ & & $m m$ \\
\hline $\mathrm{V}$ & 0.290 & Albumin & 2.9 \\
\hline IV $-6,7$ & 0.256 & Albumin & 2.8 \\
\hline IV-1 & 0.256 & Albumin, $\alpha$ - and $\beta$-globulin & 2.9 \\
\hline III -0 & 0.162 & $\beta$-Globulin & 5.3 \\
\hline I I I-1,2 & 0.308 & $\beta$ - and $\gamma$-Globulin & 12.0 \\
\hline II & 0.258 & $\gamma$-Globulin & 3.5 \\
\hline$I+I I I-3$ & 0.278 & $\gamma-$ and $\beta$-Globulin & 14.3 \\
\hline $\mathrm{VI}$ & 0.065 & Not done & 2.9 \\
\hline Saline control & 0.000 & & 2.8 \\
\hline
\end{tabular}

* Prepared by method 10 of Cohn and associates (20).

$\dagger$ Determined in 1:4 dilution with Folin phenol reagent and expressed as concentration of a standard solution of crystalline egg albumin.

$\ddagger$ Determined by visual inspection of paper electrophoretic patterns of the fractions.

$\S$ Average of 6 tests in 3 animals, performed after saline dialysis; lesion size is given in millimeters.

DEAE cellulose can be seen. At ionic strengths producing conductivities between 0.01 to 0.03 mhos, a mixture of $\gamma$ - and $\beta$-globulins was eluted from the column. This mixture appears as a double-humped peak in serum III, and as a rising shoulder, less well resolved, in serum IV, where the ionic gradient rose more sharply. A major peak of protein concentration containing albumin, and $\alpha$ - and $\beta$-globulins was eluted next at 0.05 mhos. Permeability activity is represented by the shaded areas and in both samples, two, nondialyzable, discrete peaks of permeability-inducing sub- stances were found. The first of these, A, was eluted in both samples with the serum $\gamma$-globulins at a buffer conductivity of 0.0066 mhos. The second peak, B, desorbed from the column at higher ionic strength, appearing at 0.0244 mhos in IV and 0.0200 mhos in sample III. B was present with a mixture of $\gamma$ - and $\beta$-globulins.

These findings afford further evidence of the presence of two distinct globulin permeability factors in these sera. To ascertain the relationship between the electrophoretic and chromatographic findings, however, it was necessary to perform

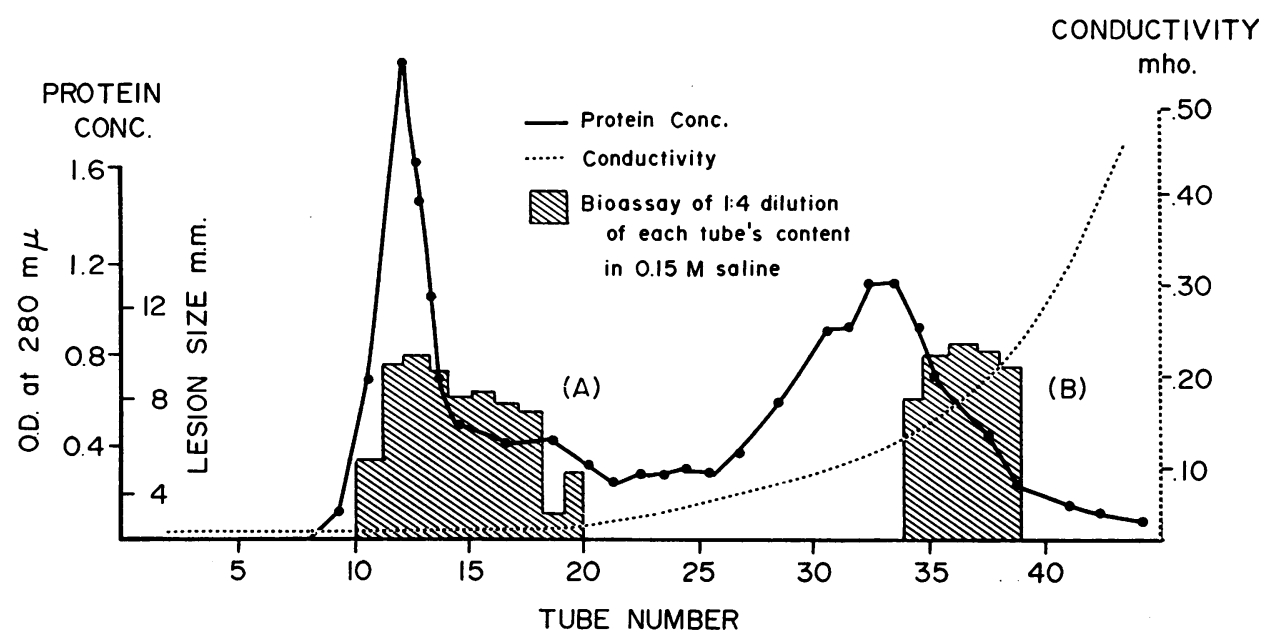

Fig. 4. DEAE-CEllulose chromatography of Fraction I + III-3. Starting buffer $0.005 \mathrm{M}$ phosphate, conductivity 0.0068 mhos, $\mathrm{pH} 8.00$; final buffer $1 \mathrm{M} \mathrm{NaCl}$, conductivity mhos, $\mathrm{pH}$ $8.0 ; 10 \mathrm{ml}$ collected in each tube; column $33.5 \times 2 \mathrm{~cm}$ packed under $6 \mathrm{lbs}$ per inch $^{2}$ pressure (about $15.2 \mathrm{~g} \mathrm{DEAE} \mathrm{celluloce);} \mathrm{concentration} \mathrm{of} \mathrm{final} \mathrm{buffer} \mathrm{in} \mathrm{Varigrad} \mathrm{chamber} \mathrm{1,} \mathrm{0 \% ;} \mathrm{2,}$ $2 \%, 3,10 \% ; 4,15 \% ; 6,5 \% ; 7,20 \% ; 8,30 \%$; and $9,100 \%$. 


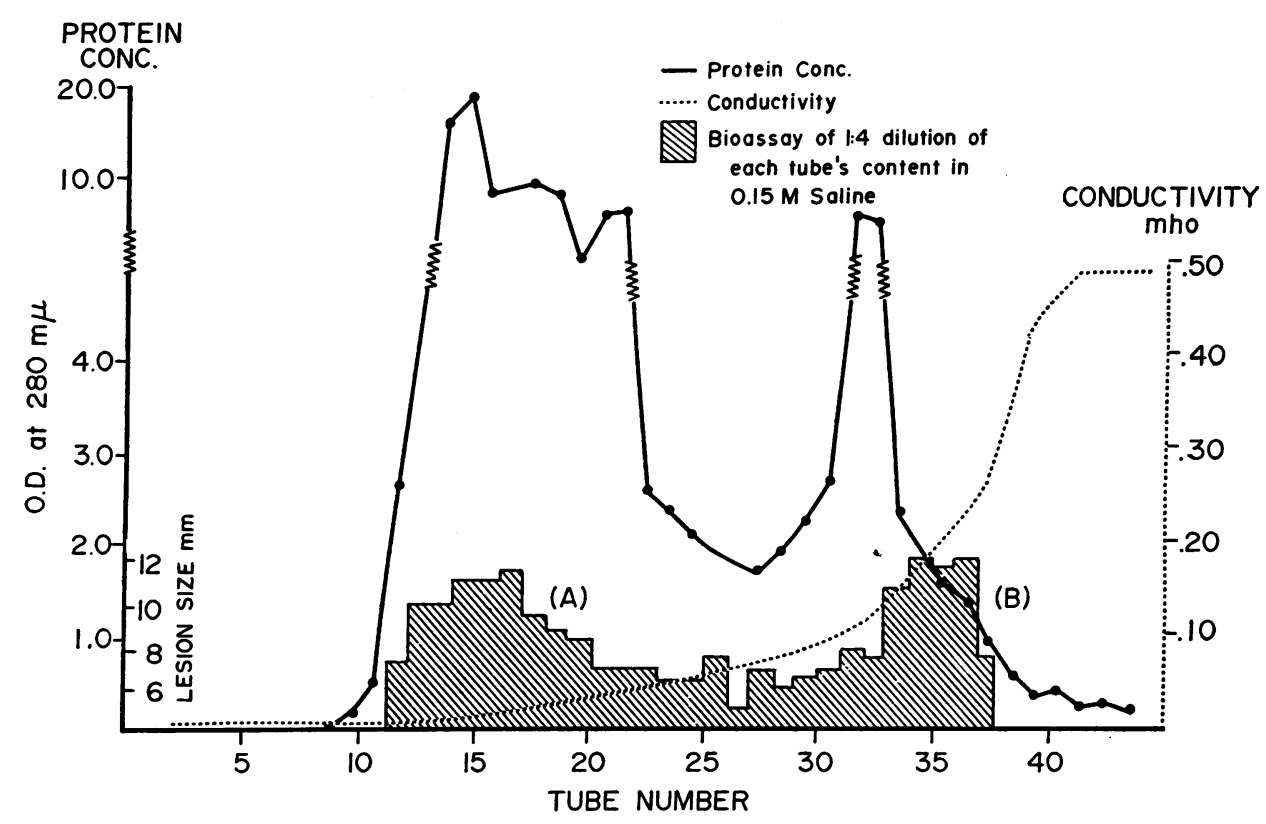

Fig. 5. DEAE-cellulose chromatography of fraction III-1, 2. Starting buffer $0.005 \mathrm{M}$ phosphate, conductivity 0.0068 mhos, $\mathrm{pH} 8.0$; final buffer $1 \mathrm{M} \mathrm{NaCl}$, conductivity 0.500 mhos, pH $8.0 ; 10 \mathrm{ml}$ collected in each tube; column $33.5 \times 2 \mathrm{~cm}$ packed under $6 \mathrm{lbs}$ per inch ${ }^{2}$ pressure (about $15.2 \mathrm{~g} \mathrm{DEAE}$ cellulose); concentration of final buffer in Varigrad chamber 1, 0\%; 2, 2\%; $3,10 \% ; 4,15 \% ; 5,15 \% ; 6,5 \% ; 7,20 \%, 8,30 \%$; and $9,100 \%$.

these procedures successively on the same serum sample. To do this, a larger amount of starting material was needed. Therefore, preliminary fractionation of larger volumes of serum by ethanol was performed.

Ethanol fractionation of pooled human serum. A volume of $247 \mathrm{ml}$ of human serum, pooled from four donors, was fractionated according to method 10 of Cohn and associates (19). Table I indicates the bioactivity of these fractions, tested after dialysis against $0.15 \mathrm{M}$ saline. Most activity was present in fractions I + III-3, and III-1, 2, with much less activity in fraction III-0.

$D E A E$-cellulose column chromatography of active ethanol fractions. Figure 4 demonstrates the results of DEAE-cellulose chromatography of fraction I + III-3. This procedure revealed two peaks of permeability activity. A eluted at 0.0066 mhos, precisely its behavior in whole serum. B eluted at 0.116 mhos, demonstrating a greater binding affinity than in whole serum. Chromatography of fraction III-1, 2 is shown in Figure 5. These results are similar to those obtained with I + III-3, except that in this sample, in which more protein was applied, the degree of resolution was poorer. Peak A desorbed at 0.0067 mhos, and $\mathrm{B}$, at 0.120 mhos. Chromatography of fraction III-0 showed a small amount of only peak A, which eluted at 0.0068 mhos. It was evident that the preliminary ethanol fractionation produced two fractions rich in permeability activity, and that both ethanol fractions contained the same two chromatographically identifiable permeability factors. Therefore, eluates collected between buffer conductivities of 0.0066 and 0.030 mhos from chromatography of both ethanol fractions were pooled as eluate A. Eluate B was obtained by pooling eluates with conductivities between 0.13 and 0.28 mhos, obtained after chromatography of the two ethanol fractions.

Starch-block electrophoresis of chromatographic eluates $A$ and $B$. Eluates $\mathrm{A}$ and $\mathrm{B}$, concentrated by ultrafiltration (17) to final volumes of 12.5 and $4.8 \mathrm{ml}$, respectively, were subjected to preparative starch-block electrophoresis. For this experiment, the block was divided by two Lucite partitions into three parallel channels, so that three samples were run simultaneously under the same conditions. Figure 6 shows the results of electrophoresis of $A, B$, and the pooled serum sample from which 


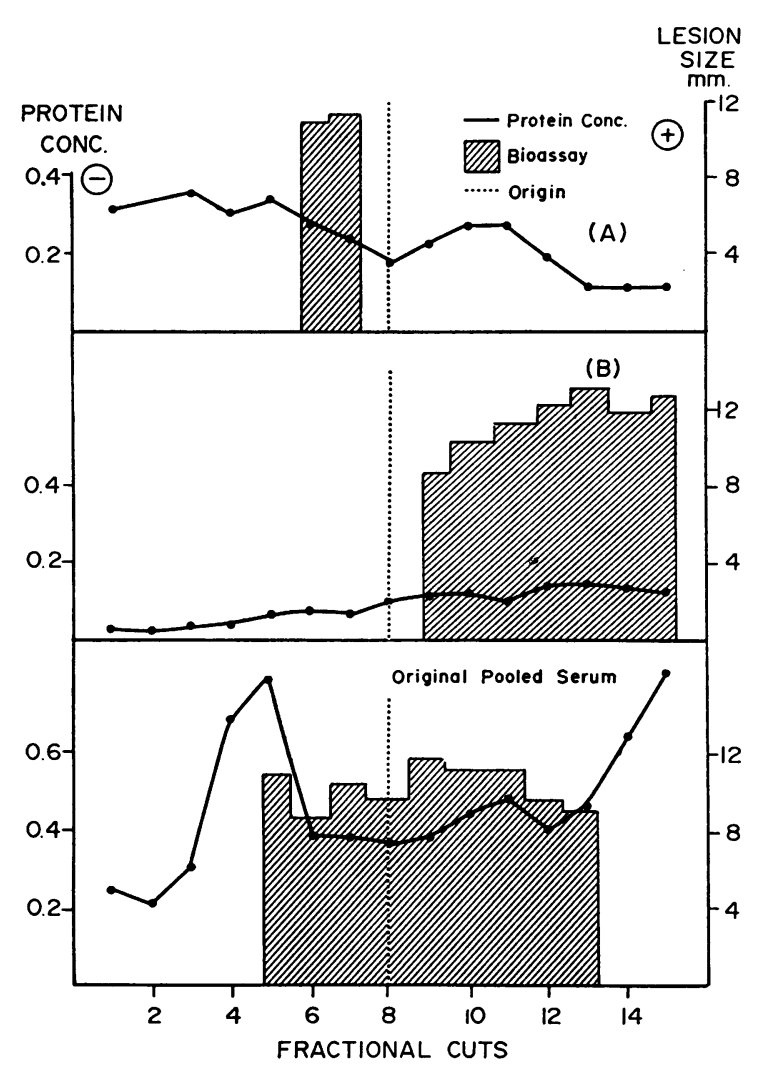

Fig. 6. STARCH-BLOCK ELECTROPHORESIS OF (A) AND (B) DERIVED FROM DEAE-CELlULOSE CHROMATOGRAPHY. Protein concentration is expressed as optical density at $700 \mathrm{~m} \mu$ determined by Folin phenol method. Fractional cuts are $2 \mathrm{~cm}$ wide, origin $=$ segment $8,500 \mathrm{v}, 120 \mathrm{ma}$, 12 hours.

they were originally derived. It can be seen that the permeability activity of A moved backward from the origin with the $\gamma$-globulins. The permeability activity of $B$ moved toward the anode with the $\beta$-globulins. The original sample of pooled serum demonstrated an activity pattern that could be well accounted for, then, by its content of A and B. Also, B has a slightly greater mobility after the purification procedures than it had in whole serum.

Rechromatography of $A$ and $B$ after electrophoresis. The activity of $A$, recovered from the starch block by elution with $0.15 \mathrm{M}$ saline, was bioassayed and applied to a DEAE-cellulose column. Chromatography was carried out as shown in Figure 7, which shows a single peak of activity (A) in the same position (at 0.007 mhos) as A occupies in whole serum.

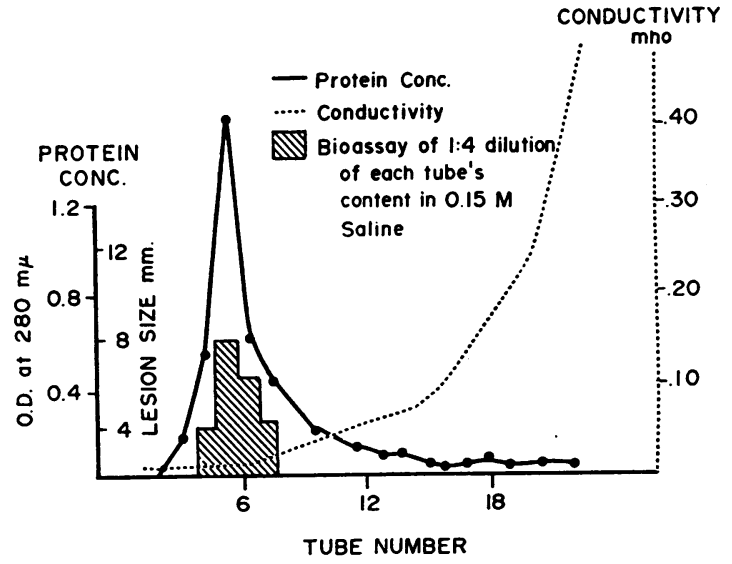

Fig. 7. DEAE-CELlulose chromatography of (A) DERIVED FROM STARCH-BLOCK ELECTROPHORESIS. Starting buffer $0.005 \mathrm{M}$ phosphate, conductivity $0.0068 \mathrm{mhos}, \mathrm{pH}$ 8.00 ; final buffer $1 \mathrm{M} \mathrm{NaCl}$, conductivity 0.498 mhos, $\mathrm{pH} 8.05 ; 10 \mathrm{ml}$ collected in each tube; column $28.2 \times 1 \mathrm{~cm}$ packed under $6 \mathrm{lbs}$ per inch ${ }^{2}$ pressure (about $2.8 \mathrm{~g} \mathrm{DEAE}$ cellulose); concentration of final buffer in Varigrad chambers $1,0 \% ; 2,2 \% ; 3,2 \% ; 4,10 \% ; 5,10 \% ; 6,2 \%$; $7,20 \% ; 8,30 \%$; and $9,100 \%$.

Recovery and rechromatography were similarly done for B. Figure 8 shows the single peak of activity eluting from the column at a conductivity of 0.110 mhos. This is similar to its chromato-

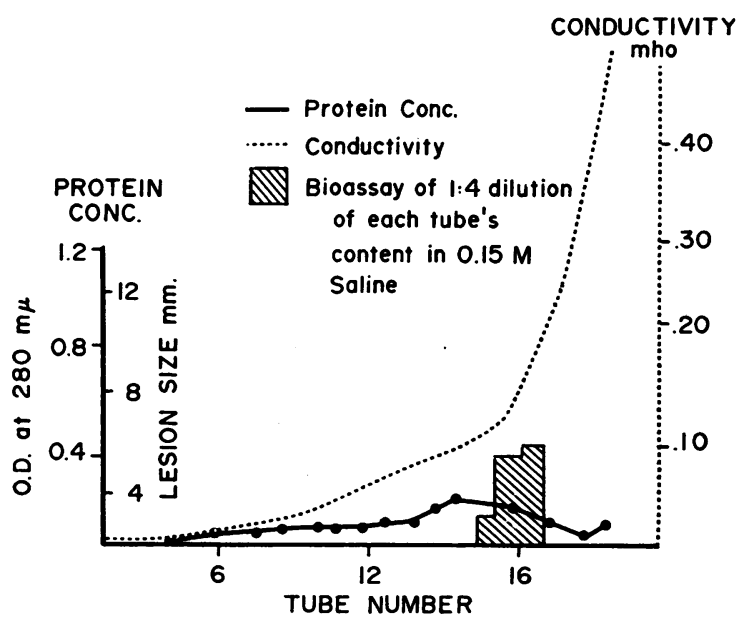

Fig. 8. DEAE-CELlulose chromatography of (B) DERIVED FROM STARCH-BLOCK ELECTROPHORESIS. Starting buffer $0.005 \mathrm{M}$ phosphate, conductivity $0.0068 \mathrm{mhos}, \mathrm{pH}$ 8.00 ; final buffer $1 \mathrm{M} \mathrm{NaCl}$, conductivity 0.498 mhos, $\mathrm{pH} 8.00 ; 10 \mathrm{ml}$ collected in each tube; column $30.5 \times 1$ $\mathrm{cm}$ packed under $6 \mathrm{lbs}$ per inch $^{2}$ pressure (about $3.0 \mathrm{~g}$ DEAE cellulose) ; concentration of final buffer in Varigrad chambers $1,0 \% ; 2,2 \% ; 3,2 \% ; 4,10 \% ; 5,10 \%$; $6,2 \% ; 7,20 \% ; 8,30 \%$; and $9,100 \%$. 
TABLE II

Inhibition of $A$ and $B$ by diisopropyl phosphofuoridate (DFP)

\begin{tabular}{lc}
\hline \multicolumn{1}{c}{ Procedure } & Bioassay* \\
\hline & $m m$ \\
A incubated with $0.15 \mathrm{M}$ saline & 9.8 \\
A incubated with $5 \times 10^{-4}$ M DFP & 3.8 \\
B incubated with 0.15 M saline & 12.2 \\
B incubated with $5 \times 10^{-4}$ M DFP & 5.4 \\
0.15 M Saline alone & 2.0 \\
\hline
\end{tabular}

* Average of 6 tests in 3 animals; incubation was for 2 hours at $4^{\circ} \mathrm{C}$; lesion size given in millimeters.

graphic behavior after ethanol fractionation. It is, however, more tightly bound to DEAE cellulose than when it was isolated directly from whole serum.

These procedures resulted in a final recovery of $7 \%$ of the original bluing activity present in the starting pooled serum. Three-quarters of this activity was recovered as globulin $B$ and onequarter as $\mathrm{A}$. Since the total original bluing activity of serum is due to $A$ and $B$ in unknown proportions, the percentage recovery for each can not be represented.

Properties of $A$ and $B$. a) Inhibition by DFP. Incubation of solutions of $A$ and $B$ with DFP in a final concentration of $5 \times 10^{-4} \mathrm{M}$ was carried out for 2 hours at $4^{\circ} \mathrm{C}$. Before bioassay, dialysis against $0.15 \mathrm{M}$ sodium chloride for 3 changes of 4 hours each was carried out to remove free DFP. The samples of both A and B treated with DFP were inactivated as shown in Table II. $b$ ) Inhibition by soybean trypsin inhibitor. Incubation of solutions of $A$ and $B$ with soybean trypsin

TABLE III

Inhibition of $A$ and $B$ by soy-bean trypsin inhibitor (SBTI)

\begin{tabular}{lc}
\hline \multicolumn{1}{c}{ Procedure } & Bioassay* \\
\hline & $\mathrm{mm}$ \\
A incubated with 0.15 M saline & 7.4 \\
A incubated with SBTI $(50 \mu \mathrm{g} / \mathrm{ml})$ & 2.5 \\
B incubated with 0.15 M saline & 9.2 \\
B incubated with SBTI $(50 \mu \mathrm{g} / \mathrm{ml})$ & 2.8 \\
0.15 M Saline alone & 2.4
\end{tabular}

* Average of 6 tests in 3 animals; incubation was for 1 hour at room temperature; lesion size given in millimeters. inhibitor in a final concentration of $50 \mu \mathrm{g}$ per $\mathrm{ml}$ was carried out for 1 hour at room temperature. As shown in Table III, soybean trypsin inhibitor inactivated both globulins A and B. c) No inhibition by an antihistaminic agent. Guinea pigs were given $20 \mathrm{mg}$ diphenhydramine hydrochloride per $\mathrm{kg}$ body weight, intraperitoneally, 2 hours before bioassay. Another group of untreated guinea pigs served as controls. A and B, for this experiment, were obtained directly from starchblock electrophoresis of whole serum. The results in Table IV indicate no inhibition of the activity of $\mathrm{A}$ or $\mathrm{B}$ by diphenhydramine. Diphenhydramine did, however, inhibit the histamine-induced permeability effect.

TABBLE IV

Lack of inhibition of $A$ or $B$ by the antihistaminic agent diphenhydramine hydrochloride

\begin{tabular}{lcc}
\hline \hline & \multicolumn{2}{c}{ Bioassay with guinea pigs* } \\
\cline { 2 - 3 } & Treatedt & Control \\
\hline A & +++ & ++ \\
B & +++ & +++ \\
Histaminet & 0 & ++ \\
Saline & 0 & 0
\end{tabular}

* Average of 8 tests in 4 animals.

t Diphenhydramine hydrochloride, $20 \mathrm{mg}$ per $\mathrm{kg}$ body weight given intraperitoneally 2 hours before bioassay.

$\ddagger$ Injected intracutaneously, $1.5 \mu \mathrm{g}$.

\section{DISCUSSION}

Serum of normal young men contains two, nondialyzable, ethanol-precipitable, permeability globulins that differ from each other in their electrophoretic mobility and chromatographic behavior. They were prepared after ethanol fractionation by chromatographic separation followed by electrophoresis and rechromatography. Globulin $\mathrm{A}$ has the mobility of serum $\gamma$-globulin, while B has that of $\beta$-globulin. Both globulin factors are inhibited by DFP and soybean trypsin inhibitor, suggesting the probable enzymatic nature of both $A$ and B. Whether these substances are both esterases as has been described for $\mathrm{PF} / \mathrm{dil}$ and kallikrein is not yet certain.

Globulin A has no affinity for DEAE cellulose, and is absorbed on carboxymethyl cellulose under the same conditions (22) as reported by Webster and Pierce for serum kallikrein (23). Further purification and correlation of properties of both 
serum kallikrein and globulin A may demonstrate that they are the same.

Miles found that human $\mathrm{PF} / \mathrm{dil}$ had the mobility of $\beta$-globulin (14). It, too, possesses esterase activity. Globulin $\mathrm{B}$ is a $\beta$-globulin that is inactivated by esterase inhibitors. The possible identity of these two factors is also suggested. After purification, globulin B attained slightly greater electrophoretic mobility and greater binding affinity for charged DEAE cellulose than when isolated directly from serum. This may arise from several possibilities. The chromatographic behavior of $B$ in whole serum may differ because of competitive displacement from the absorbent by other serum proteins. Dissociation during purification of protein-protein complexes, or cleavage, or modification of the $\mathrm{B}$ molecule itself might have occurred.

The absence of antagonism of the action of either $A$ or $B$ by diphenhydramine suggests that histamine is not a mediator of the effects of these globulins.

\section{SUMMARY}

Two permeability globulins have been separated from sera of normal young men by the techniques of ethanol fractionation, ion-exchange chromatography, and starch-block electrophoresis. The first, $A$, has the electrophoretic mobility and DEAE-cellulose chromatographic behavior of a $\gamma$-globulin. The second, B, has the electrophoretic mobility and DEAE-cellulose chromatographic behavior of a $\beta$-globulin. Both $\mathrm{A}$ and $\mathrm{B}$ globulins are inhibited by the esterase inhibitor substances diisopropyl phosphofluoridate and soybean trypsin inhibitor. Neither A nor B is inhibited by the antihistaminic agent diphenhydramine hydrochloride. A may be the same as serum kallikrein, and $\mathrm{B}$ may be the same as $\mathrm{PF} /$ dil.

\section{REFERENCES}

1. Kagen, L. J., J. P. Leddy, and E. L. Becker. Isolation of two permeability globulins from human serum. Nature (Lond.) 1963, 197, 693.

2. Frey, E. K. Zusammenhänge zwischen Herzarbeit und Nierentätigkeit. Arch. klin. Chir. 1925, 142, 663.

3. Mackay, M. E., A. A. Miles, C. B. E. Shachter, and D. L. Wilhelm. Susceptibility of the guinea pig to pharmacological factors from its own serum. Nature (Lond.) 1953, 172, 714.
4. Elliott, D. F., E. W. Horton, and G. P. Lewis. Actions of pure bradykinin. J. Physiol. 1960, 153, 473.

5. Fox, R. H., R. Goldsmith, D. J. Kidd, and G. P. Lewis. Bradykinin as a vasodilator in man. J. Physiol. 1961, 157, 589.

6. Lewis, G. P. Bradykinin. Nature (Lond.) 1961, 192, 596.

7. Landerman, N. S., M. E. Webster, E. L. Becker, and H. E. Ratcliffe. Hereditary angioneurotic edema. II. Deficiency of inhibitor for serum globulin permeability factor and/or plasma kallikrein. J. Allergy 1962, 33, 330.

8. Hilton, S. M. Plasma kinin and blood flow in Polypeptides Which Affect Smooth Muscles and Blood Vessels, M. Schachter, Ed. London, Pergamon, 1960, p. 258.

9. Chapman, L. F., H. Goodell, and H. G. Wolff. Augmentation of the inflammatory reaction by activity of the central nervous system. Arch. Neurol. (Chic.) 1959, 1, 557.

10. Becker, E. L., D. L. Wilhelm, and A. A. Miles. Enzymic nature of the serum globulin permeability factor. Nature (Lond.) 1959, 183, 1264.

11. Werle, E., and L. Maier. Uber die chemische und pharmakologische Unterscheidung von Kallikreinen verschiedener Herkunft. Biochem. Z. 1952, 323, 279.

12. Habermann, E. Diisopropylfluorsphosphat-Hemmung esterolytischer und pharmakologischer Wirkungen von Kallikrein und Schlangengiften. Naturwissenschaften 1960, 47, 111.

13. Schachter, M. Some properties of kallidin, bradykinin and wasp venom kinin in Polypeptides Which Affect Smooth Muscles and Blood Vessels, M. Schachter, Ed. London, Pergamon, 1960, p. 232.

14. Miles, A. A. Local and systemic factors in shock. Fed. Proc. 1961, 20, suppl. 9, 141.

15. Davies, G. E., and J. S. Lowe. Further studies on a permeability factor released from guinea pig serum by antigen-antibody precipitates. Int. Arch. Allergy 1962, 20, 235.

16. Miles, A. A., and D. L. Wilhelm. Enzyme-like globulins from serum reproducing the vascular phenomena of inflammation. I. An activable permeability factor and its inhibitor in guinea-pig serum. Brit. J. exp. Path. 1955, 36, 71.

17. Sober, H. A., F. J. Gutter, M. M. Wyckoff, and E. A. Peterson. Chromatography of proteins. II. Fractionation of serum protein on anion-exchange cellulose. J. Amer. chem. Soc. 1956, 78, 756.

18. Peterson, E. A., and H. A. Sober. Variable gradient device for chromatography. Analyt. Chem. 1959, 31, 857.

19. Kunkel, H. G., and R. J. Slater. Zone electrophoresis in a starch supporting medium. Proc. Soc. exp. Biol. (N. Y.) 1952, 80, 42. 
20. Cohn, E. J., F. R. N. Gurd, D. M. Surgenor, B. A. Barnes, R. K. Brown, G. Derouaux, J. M. Gillespie, F. W. Kahnt, W. F. Lever, C. H. Liu, D. Mittelman, R. F. Mouton, K. Schmid, and E. Uroma. A system for the separation of the components of human blood: quantitative procedures for the separation of the protein components of human plasma. J. Amer. chem. Soc. 1950, 72, 465.
21. Lowry, O. H., N. J. Rosebrough, A. L. Farr, and R. J. Randall. Protein measurement with the Folin phenol reagent. J. biol. Chem. 1951, 193, 265.

22. Kagen, L. J. Unpublished results.

23. Webster, M. E., and J. V. Pierce. Action of the kallikreins on synthetic ester substrates. Proc. Soc. exp. Biol. (N. Y.) 1961, 107, 186. 